\title{
Titanium Coating with Hydroxyapatite and Chitosan Doped with Silver Nitrate
}

\author{
Lucíola Lucena de Sousa ${ }^{a}$, Virgilio Pereira Ricci ${ }^{a}$, Deborah Gouvêa Prado ${ }^{a}$, Raira Chefer \\ Apolinario $^{a}$, Luci Cristina de Oliveira Vercik ${ }^{b}$, Eliana Cristina da Silva Rigo ${ }^{b}$, Mérilin Cristina dos
}

Santos Fernandes ${ }^{c}$, Neide Aparecida Mariano ${ }^{a}$
anniversidade Federal de Alfenas - UNIFAL, Campus Avançado de Poços de Caldas, Rod. José Aurélio Vilela, BR 267-Km 533, Cidade Universitária, Poços de Caldas, 377015-400, MG, Brazil
${ }^{b}$ Departamento de Ciências Básicas, Faculdade de Zootecnia, Engenharia de Alimentos -
FZEA, Universidade de São Paulo - USP - Pirassununga, Avenida Duque de Caxias Norte 225,
Pirassununga, 13635-900, SP, Brazil
${ }^{c}$ Universidade Estadual Paulista - Júlio de Mesquita Filho - UNESP, Campus de Itapeva, Rua Geraldo Alckmin, 519, 18409-010, Itapeva, SP, Brazil

Received: January 10, 2017; Revised: December 18, 2017; Accepted: December 20, 2017

\begin{abstract}
Biomaterials are effective alternatives for tissue substitution, including the bone tissue, since they do not pose risks of transmission of diseases or immune rejection. Nowadays, there is an interest in new materials capable of being associated with other substances which favor bone formation, especially natural biopolymers, in particular chitosan, which may present a potential for repairing bone defects and forms films that adhere to metal surfaces. Titanium, despite being a material greatly employed in implants because of its excellent physical properties, does not present bioactive characteristics, making it necessary to use methods of surface modification to enhance its biological response, favoring bone formation. This work aims at studying commercially pure titanium (cp-Ti) coating with chitosan using the biomimetic method and the evaluation of the effects of process variables as substrate surface conditions. Subsequently, the incorporation of AgNO3 was studied and its effects on corrosion resistance were evaluated. To evaluate the coating process, several tests were conducted, such as scanning electron microscopy, X-ray diffraction and infrared spectroscopy. From the results obtained, the efficacy of the chitosan film in inhibiting the corrosion of the metals is concluded, which was the target of this study, thus justifying its use for osseointegration and in several implants.
\end{abstract}

Keywords: Chitosan, Titanium, Biomimetic Method, Biomaterial.

\section{Introduction}

Biomaterial is a material used to interact with the organism, substituting or improving tissues, organs and functions in the body. The research on biomaterials is directed to several areas, such as: science, chemistry, physics, biology and medicine, in the search to obtain a device that, in addition to an excellent mechanical resistance, offers good bioactivity and compatibility when in contact with biological tissues. Thus, the performance and application of biomaterials are extremely important for the development and improvement of biomedical implants and tissues.

Titanium and its alloys are prominent for presenting biocompatibility, high resistance to corrosion and a relatively low density, becoming important materials for research in the field of Biomedicine ${ }^{1-5}$. Nevertheless, results confirm that the bioactive materials in the surface of the implant favor osseointegration time. To accelerate this process, modifications in the surface of the materials are being studied ${ }^{6,7}$, especially to improve the interaction of metal alloys with the biological system, by techniques of coating for the formation of a hydroxyapatite layer, which is a bioactive material that

*e-mail: luciolalucena@gmail.com favors bone tissue regeneration, avoiding possible damages to the person with the implant.

The method of biomimetic coating ${ }^{8-10}$ is widely employed in titanium substrates, and consists in the formation of a hydroxyapatite layer with the immersion of the substrate in simulated body fluid (SBF) $)^{11-15}$. A way of minimizing possible rejections of the organism is by doping this layer with silver nitrate, which is renowned as bactericidal ${ }^{16}$, and with the need of controlling silver nitrate $\left(\mathrm{AgNO}_{3}\right)$ release, a chitosan coating can be used on the substrate. Chitosan is a natural polymer, biocompatible, biodegradable, bioabsorbable and non-toxic to the organism, and has been increasingly used in the pharmaceutical industry and in the biomedical field, due to its capacity of slowly releasing the medicines that will be used, as well as because of its antimicrobial capacity ${ }^{17-20}$.

The effect of corrosion on the implants is an important factor, since the release of ions in the organism can be very detrimental to the health of the person with the implant. It can also lead to a loss in implant efficiency and, as a consequence, its substitution before the scheduled time.

Therefore, the aim of this work was to study the commercially pure titanium (cp-Ti), covered with hydroxyapatite by the biomimetic method and doped with silver nitrate. Additionally, 
with the need of controlling its release, a further coating with chitosan was performed. The behavior regarding corrosion in body fluid (simulated body fluid) was also analyzed.

\section{Materials and Methods}

Table 1 depicts the chemical composition of the substrate, commercially pure titanium (cp-Ti) grade 4. It was determined by inductively coupled plasma optical emission spectrometry (ICP-OES). The composition of cp-Ti in this work is in accordance with standard specifications and equivalent to cp-Ti grade 4.

The biomimetic method was employed for cp-Ti coating with hydroxyapatite. This method consists initially in an alkaline treatment, in which the substrate is submerged in a $5 \mathrm{M} \mathrm{NaOH}$ solution at $60^{\circ} \mathrm{C}$ for 24 hours, to produce active sites on the metal surface, in order to favor hydroxyapatite precipitation $^{5,19}$. Subsequently, the substrate was subjected to a heat treatment at $600^{\circ} \mathrm{C}$ for one hour and cooled at room temperature, to eliminate the hydrated phase and form a stable layer. Then, the substrate was subjected to a nucleation step, which consists in the immersion in a sodium silicate solution at $36.5^{\circ} \mathrm{C}$ for seven days. The substrate was then immersed in a $1.5 \mathrm{SBF}(\mathrm{pH}=7.4)$ solution at $36.5^{\circ} \mathrm{C}$ for seven days, changing the solution every forty-eight hours to increase saturation and accelerate hydroxyapatite growth rate, a condition which was called Condition Zero ( $\mathrm{C} 0)$.

After the biomimetic coating, the substrate was submerged in a solution with $10 \mathrm{ppm}$ of $\mathrm{AgNO}_{3}$ for forty-eight hours at $36.5^{\circ} \mathrm{C}$ (doping with $\mathrm{AgNO}_{3}$ ); subsequently, the sample was covered with $1 \%$ of chitosan (of medium molecular weight). Chitosan was prepared using a solution of $1 \%$ acetic acid with stirring for $1 \mathrm{~h}$, at $\mathrm{pH} 6.41$; then, the samples were immersed in this solution for 5 seconds.

Subsequently, the samples were dried at room temperature inside a desiccator, a condition called Condition 1 (C1). Table 2 presents the description of the conditions of the coatings used in the substrate (cp-Ti).

The microstructural cp-Ti characterization was performed by optical microscopy (OM) and scanning electron microscopy coupled to an energy dispersive $\mathrm{X}$ ray spectrometer (SEM-EDS), according to the norm ASTM E3-95 ${ }^{14}$. The microstructure was revealed with a Kroll solution (5\% of nitric acid, $10 \%$ of hydrofluoric acid and $85 \%$ in volume of distilled water).

$\mathrm{X}$-ray diffraction (XRD) and diffuse reflectance FourierTransform infrared Spectroscopy (FTIR) were used to characterize the cp-Ti and the coatings employed. XRD analyses were performed with $\mathrm{Cu} \mathrm{K} \alpha$ radiation, in a range
Table 2. Description of the coating conditions used in this work

\begin{tabular}{lc}
\hline Condition Zero $(\mathrm{C} 0)$ & Condition $1(\mathrm{C} 1)$ \\
\hline Ti c.p $+\mathrm{HA}$ & Ti c.p $+\mathrm{HA}+\mathrm{AgNO}_{3}+\mathrm{CH}$ \\
\hline $\begin{array}{l}\text { Ti c.p }=\text { commercially pure titanium; } \mathrm{HA}=\text { hydroxyapatite; } \mathrm{CH}= \\
\text { chitosan }\end{array}$
\end{tabular}

of $2 \theta$ from $10^{\circ}$ to $90^{\circ}$, with a stepof $0.02^{\circ}$ for $2 \mathrm{~s} / \mathrm{step}$. The FTIR analyses were performed to determine the functional groups that characterize the hydroxyapatite and chitosan coatings, by the absorption bands in a frequency that is characteristic of radiation, in the infrared region.

The assays of differential scanning calorimetry (DSC) and thermogravimetric analysis (TG) were conducted at $1100^{\circ} \mathrm{C}$, with a heating and cooling rate of $10^{\circ} \mathrm{C} / \mathrm{min}$, using argon as carrier gas.

The assays of corrosion by open circuit polarization (OCP) and potentiodynamic polarization were performed using an electrochemical cell, working electrode, platinum counter electrode and the saturated calomel reference electrode (SCE). The electrolytic solution was $1.5 \mathrm{SBF}$ at $\mathrm{pH} 7.4$, at the temperature $36.5^{\circ} \mathrm{C}$. The polarization curves were obtained by varying the potential (E) from $-1.5 \mathrm{~V}$ (SCE) to $3.0 \mathrm{~V}$,with a $0.001 \mathrm{~V}$ step and scanning speed of $0.001 \mathrm{~V} /$ second.

\section{Results and Discussion}

Figure 1 shows cp-Ti micrograph, where a homogeneous distribution can be observed for the grains with equiaxial shape and that are well-distributed in the matrix, characteristic of cp-Ti phase $\alpha$.

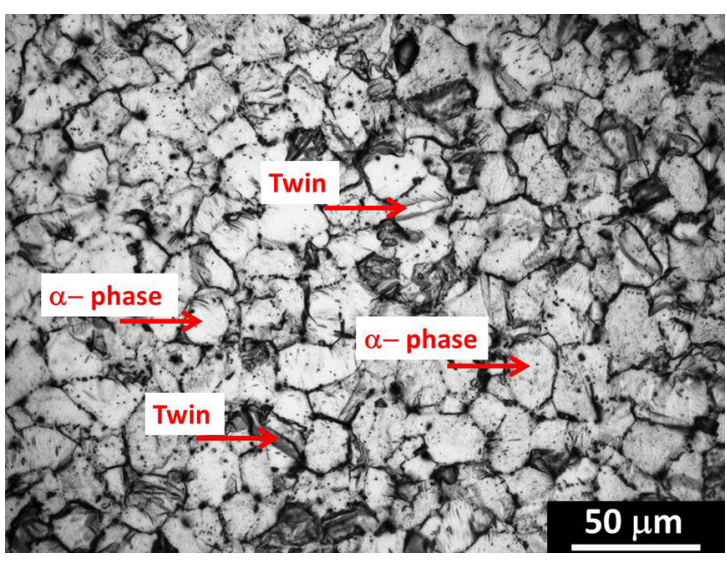

Figure 1. cp-Ti micrograph obtained by OM. Reagent: Kroll solution.

Table 1. Chemical composition of cp-Ti grade 4 (in \% weight) $)^{13}$

\begin{tabular}{lcccccc}
\hline Sample & $\mathrm{N}$ & $\mathrm{C}$ & $\mathrm{H}$ & $\mathrm{Fe}$ & $\mathrm{O}$ & $\mathrm{Ti}$ \\
\hline Titanium grade 4 & 0,05 máx. & 0,08 máx. & 0,015 máx. & 0,50 máx. & 0,40 máx. & Bal. \\
\hline
\end{tabular}


Figure 2 presents the thermograms obtained in the assays of differential scanning calorimetry (DSC) and thermogravimetric analysis (TG) of cp-Ti.
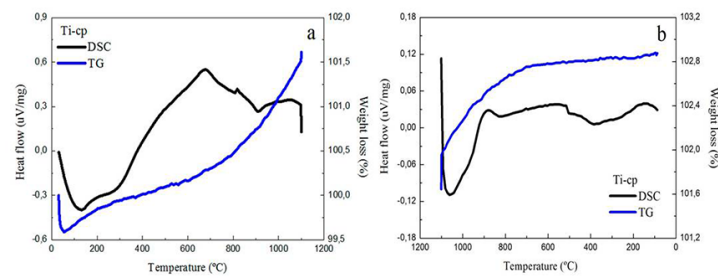

Figure 2. DSC and TG curves of cp-Ti performed at $1100^{\circ} \mathrm{C}$. (a) Heating. (b) Cooling.

In Figure 2a, there is a reaction until the temperature of $118^{\circ} \mathrm{C}$, deriving from the loss of molecular water present in the sample. At approximately $907^{\circ} \mathrm{C}$, the existing peak is due to the transformation from phase $\alpha$ to phase $\beta$. Phase $\alpha$ is characterized by the presence of a compact hexagonal crystalline structure (HC) and for being stable at room temperature, whereas phase $\beta$ is composed of a body-centered cubic crystalline structure (CCC), stable up to the fusion temperature of the material.

The difference between the obtained and theoretical values of the allotropic transformation $\left(882^{\circ} \mathrm{C}\right)$ derives from the fact that titanium grade 4 , used in this work, has alloy elements $(\mathrm{N}, \mathrm{C}, \mathrm{H}, \mathrm{Fe}, \mathrm{O})$, that can distort the theoretical values of highly pure titanium. A transformation peak was also observed at $675^{\circ} \mathrm{C}$, which indicates the transformation of $\mathrm{TiO}_{2}$ from anatase to rutile, despite the inert atmosphere (argon). These transformations were also observed in the cooling curve.

In the thermogravimetry (TG) assays for cp-Ti, shown in Figure 2 a, a mass gain of $3.3 \%$ is observed, as a result of $\mathrm{TiO}_{2}$ formation on the surface of the material. The initial mass reduction, of approximately $0.45 \%$ (in mass), indicates molecular water loss. The rise in cp-Ti mass coincides with the temperature of $\mathrm{TiO}_{2}$ formation, demonstrated in the curves of differential scanning calorimetry (DSC).

Figure 3 present the micrograph, obtained by SEM, of the sample with coating at conditions $\mathrm{C} 0$ ( $\mathrm{cp}-\mathrm{Ti}+\mathrm{HA})$. Figures $3 a$ and $3 b$ depicts the surface of $c p-T i$ after coating at condition $\mathrm{C} 0$, where the formation of a homogeneous layer is observed, in globular shape and well-distributed on the substrate.This structure occurs because of the previous treatments, the alkaline treatment and the heat treatment. In the alkaline treatment, the active $\mathrm{TiO}_{2}$ sites react with calcium and phosphorus and rise hydroxyapatite nucleation rate, while the heat treatment stabilizes in the form of sodium titanate $\left(\mathrm{Na}_{2} \mathrm{Ti}_{5} \mathrm{O}_{11}\right)$, partially crystalized, being responsible for the acceleration of hydroxyapatite growth ${ }^{18,19}$.

It is possible to observe the formation of three hydroxyapatite layers, and as layer overlap occurs, it is observed that the coating structure has a more globular shape and these globules

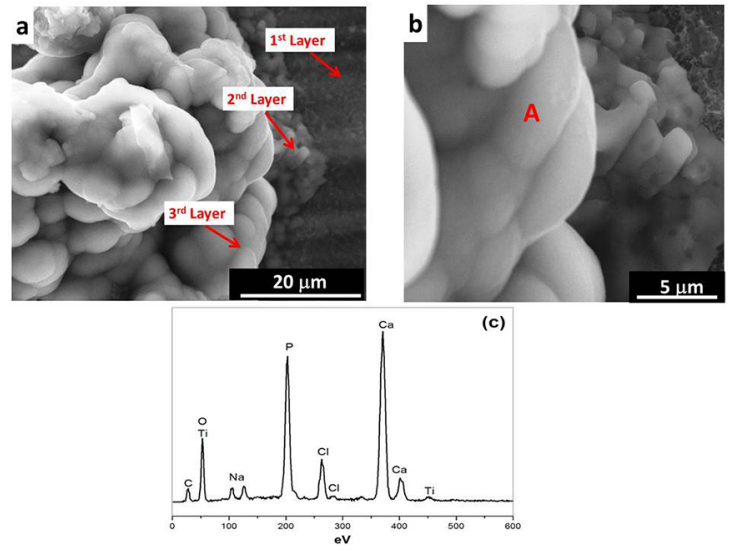

Figure 3. (a) and (b) Micrograph of cp-Ti at $\mathrm{CO}$ (cp-Ti+ HA), obtained by SEM. (c) Spectrum obtained in the microanalysis by EDS at point $\mathrm{A}$.

have a larger diameter than the previous layer, indicating that as overlap occurs, the layer that forms subsequently limits the growth of the previous layer.

Figure $3 \mathrm{c}$ shows the spectrum obtained in the microanalysis by EDS, at point $\mathrm{A}$, and in the semi-quantitative analysis, the presence of the elements phosphorus $(\mathrm{P})$ and calcium $(\mathrm{Ca})$, present in the hydroxyapatite structure $\left[\mathrm{Ca}_{10}\left(\mathrm{PO}_{4}\right)_{6}(\mathrm{OH})_{2}\right]$, was observed. Furthermore, the presence of the element oxygen (O) can derive from the formation of the hydroxyapatite structure $\left[\mathrm{Ca}_{10}\left(\mathrm{PO}_{4}\right)_{6}(\mathrm{OH})_{2}\right]$ and/or of surface contamination, as well as carbon (C). The presence of chlorine and sodium can derive from the reagents used in the preparation of the solution of $1.5 \mathrm{SBF}$, and the presence of sodium can also result from the alkaline treatment.

The X-ray diffraction (XRD) results corroborate those obtained by microscopy. Figure 4a shows the spectrum for condition $\mathrm{C} 0$ (cp-Ti+HA), and the formation of hydroxyapatite is observed, as well as the peaks characteristic of phase $\alpha$. These results were also observed by Coelho et.al. ${ }^{8}$ and Erakovic et. al. ${ }^{20}$.
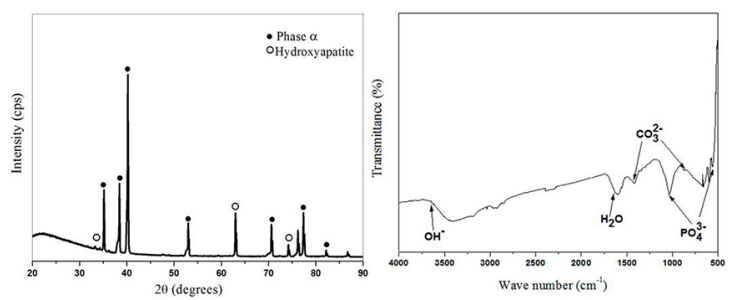

Figure 4. Characterization of $\mathrm{cp}-\mathrm{Ti}$ at condition $\mathrm{C} 0(\mathrm{cp}-\mathrm{Ti}+\mathrm{HA})$. (a) X-ray diffractogram. (b) Infrared spectrum.

The results of diffuse reflectance Fourier-Transform infrared spectroscopy (FTIR) of condition C0 (cp-Ti+HA) depicted in Figure $4 \mathrm{~b}$ confirms the results obtained by SEM/EDS and XRD. By the spectra, hydroxyapatite was identified by the absorption bands relative to the vibration of groups $\mathrm{PO}_{4}^{3-}\left(1014 \mathrm{~cm}^{-1}\right)$ and $\mathrm{OH}^{-}\left(3631 \mathrm{~cm}^{-1}\right)$. The peak at 
$1611 \mathrm{~cm}^{-1}$ corresponds to the water absorbed by the sample. The peaks at $1412 \mathrm{~cm}^{-1}$ and $880 \mathrm{~cm}^{-1}$ are related, respectively, to the stretching and vibration of the group $\mathrm{CO}_{3}{ }^{2-}$ of the type $\mathrm{A}$ and $\mathrm{B}$, thus characterizing hydroxyapatite type $\mathrm{AB}$. These results were also observed by Coelho et. al. ${ }^{8}$ and Lafron $^{21}$.

Figures $5 \mathrm{a}$ and $5 \mathrm{~b}$ illustrates the surface of cp-Ti after coating at condition $\mathrm{C} 1\left(\mathrm{cp}-\mathrm{Ti}+\mathrm{HA}+\mathrm{AgNO}_{3}+\mathrm{CH}\right)$, obtained by SEM, where the presence of chitosan, hydroxyapatite and silver nitrate agglomerates is observed. These agglomerates are formed because of the capacity of chitosan to form complexes with metal ions, in this case silver ions, besides the fact that the coating with hydroxyapatite presents a porous surface and roughness on its surface. It is also possible to notice a homogeneous layer without the presence of pores on the hydroxyapatite coating doped with silver nitrate.

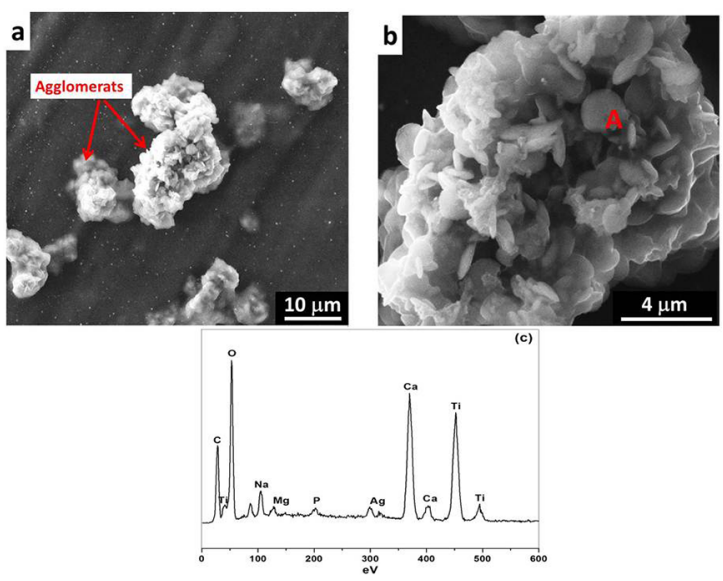

Figure 5. (a) and (b) Micrograph of cp-Ti at $\mathrm{Cl}$ (cp-Ti+HA+AgNO3+CH), obtained by SEM. (c) Spectrum obtained in the microanalysis by EDS at point $\mathrm{A}$.

Figure $5 \mathrm{c}$ shows the spectrum obtained in the microanalysis by EDS, at point A, and in the semi-quantitative analysis there was an increase in peak intensity of the elements carbon $(\mathrm{C})$ and oxygen $(\mathrm{O})$ at condition $\mathrm{C} 1$, in comparison with condition $\mathrm{C} 0$, which might indicate the presence of chitosan. Oxygen is also present in hydroxyapatite structure $\left[\mathrm{Ca}_{10}\left(\mathrm{PO}_{4}\right)_{6}(\mathrm{OH})_{2}\right]$, as well as the elements phosphorus $(\mathrm{P})$ and calcium $(\mathrm{Ca})$. The presence of silver ions $(\mathrm{Ag})$ is related to the doping with silver nitrate. Additionally, sodium $(\mathrm{Na})$ and magnesium $(\mathrm{Mg})$ are derived from the solution of 1.5 SBF.

The results of X-ray diffraction (XRD) and of diffuse reflectance Fourier-Transform infrared spectroscopy (FTIR) are presented in Figure 6, and corroborate the results obtained by SEM/EDS. In the X-ray spectra, Figure $6 \mathrm{a}$, the presence of hydroxyapatite, phase $\alpha$ and chitosan is observed at condition $\mathrm{Cl}$ (cp- $\left.\mathrm{Ti}+\mathrm{HA}+\mathrm{AgNO}_{3}+\mathrm{CH}\right)$. The identification of the characteristic chitosan peak was confirmed by the XRD spectrum, performed on the film of pure chitosan, as also observed by Zhou et. al. ${ }^{22}$.

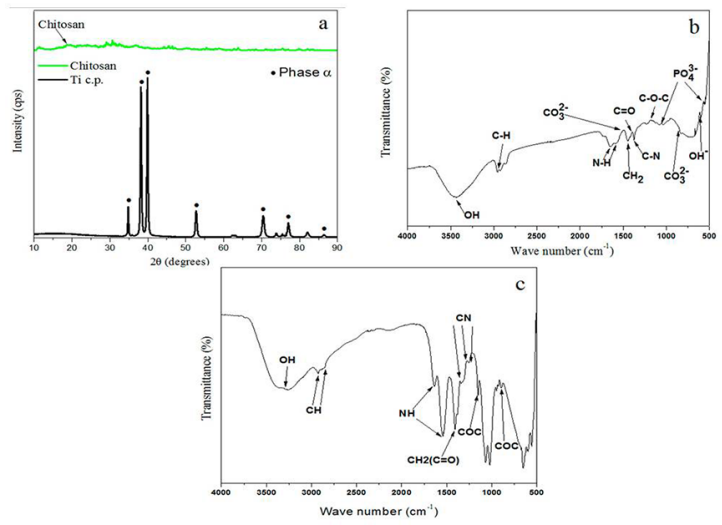

Figure 6. (a) X-ray diffraction (XRD) at condition $\mathrm{C} 1$ (cp$\mathrm{Ti}+\mathrm{HA}+\mathrm{AgNO}_{3}+\mathrm{CH}$ ) and chitosan film. (b) Infrared spectrum at condition $\mathrm{Cl}\left(\mathrm{cp}-\mathrm{Ti}+\mathrm{HA}+\mathrm{AgNO}_{3}+\mathrm{CH}\right)$. (c) Infrared spectrum of the chitosan film.

The infrared spectrum of condition $\mathrm{C} 1$ (cp$\mathrm{Ti}+\mathrm{HA}+\mathrm{AgNO}_{3}+\mathrm{CH}$ ), illustrated in Figure $6 \mathrm{~b}$, presents the bands at $3439 \mathrm{~cm}^{-1}$ relative to the stretching of $\mathrm{OH}$, at $2849 \mathrm{~cm}^{-1}$ referring to the stretching of group $\mathrm{CH}$, at 1568 and at $1650 \mathrm{~cm}^{-1}$, the folding of group $\mathrm{NH}$, at $1423 \mathrm{~cm}^{-1}$, the folding of group $\mathrm{CH} 2$, at $1406 \mathrm{~cm}^{-1}$, folding of group $\mathrm{C}=\mathrm{O}$, $1379 \mathrm{~cm}^{-1}$, folding of group $\mathrm{CN}$, at $1154 \mathrm{~cm}^{-1}$, stretching of group COC, bands which refer to chitosan.

The bands corresponding to hydroxyapatite are identified at $1514 \mathrm{~cm}^{-1}$ for stretching of group $\mathrm{CO}_{3}{ }^{2-}$ type $\mathrm{A}$, at 870 $\mathrm{cm}^{-1}$, vibration of group $\mathrm{CO}_{3}{ }^{2-}$ type $\mathrm{B}$, thus characterizing the hydroxyapatite formed as type $\mathrm{AB}$ at $1059 \mathrm{~cm}^{-1}$ stretching, at $566 \mathrm{~cm}^{-1}$ vibration of the group $\mathrm{PO}_{4}{ }^{3-}$ and at $630 \mathrm{~cm}^{-1}$ the vibration of group $\mathrm{OH}^{-}$.

Chitosan, when in contact with $\mathrm{Ag}^{+}$ions, suffers an alteration, combining the hydroxyl groups and/or amino groups. Figure $6 \mathrm{c}$ shows the infrared spectra of the chitosan film. The peaks at $3259 \mathrm{~cm}^{-1}$ correspond to the stretching of the $\mathrm{OH}$ group. With wave number at 2919 and $2878 \mathrm{~cm}^{-1}$ are the peaks related to the stretching of the $\mathrm{CH}$ group. The peaks corresponding to the folding of the $\mathrm{N}-\mathrm{H}$ group are identified at 1647 and 1545 $\mathrm{cm}^{-1}$. The peak at $1406 \mathrm{~cm}^{-1}$ refers to the stretching of group $\mathrm{CH}_{2}(\mathrm{C}=\mathrm{O})$. The peak at $1331 \mathrm{~cm}^{-1}$ corresponds to the folding of group $\mathrm{C}-\mathrm{N}$, whereas that at 1321 and $1260 \mathrm{~cm}^{-1}$ is related to the stretching of group C-N. The peak at 1154 and $896 \mathrm{~cm}^{-1}$ refers to the stretching of group C-O-C.

The results of the assay of corrosion with open circuit polarization (OCP) are presented in Figure 7a. In samples $\mathrm{C} 0$ and $\mathrm{C} 1$, the potential remained constant with time, which indicates the stability of the coatings and also suggests that these coatings are adherent to the titanium surface at condition $\mathrm{C} 0$, whereas at condition $\mathrm{C} 1$, the coating is adherent to the surface of hydroxyapatite doped with silver nitrate.

The polarization curves are presented in Figure $7 \mathrm{~b}$. The values of corrosion potential $\left(\mathrm{E}_{\text {corr }}\right)$, corrosion current density $\left(\mathrm{I}_{\text {corr }}\right)$ and passivation current density (Ipass) are presented in Table 3. 
Table 3. Electrochemical parameters obtained in $1.5 \mathrm{SBF}$ at $36.5^{\circ} \mathrm{C}$ for $\mathrm{cp}-\mathrm{Ti}$

\begin{tabular}{llll}
\hline Conditions & $\mathrm{E}_{\text {corr }}(\mathrm{V})$ & $\mathrm{I}_{\text {corr }}\left(\mathrm{A} / \mathrm{cm}^{2}\right)$ & $\mathrm{I}_{\text {pass }}\left(\mathrm{A} / \mathrm{cm}^{2}\right)$ \\
\hline Ti c.p. & -0.526 & $7.867 \times 10^{-7}$ & $1.116 \times 10^{-5}$ \\
Ti c.p+ HA & -0.321 & $8.404 \times 10^{-7}$ & $5.472 \times 10^{-5}$ \\
Ti c.p+HA+ $\mathrm{AgNO}_{3}+\mathrm{CH}$ & 0.190 & $1.701 \times 10^{-7}$ & $2.398 \times 10^{-6}$ \\
\hline
\end{tabular}

$\mathrm{E}_{\text {corr }}=$ corrosion potential; $\mathrm{I}_{\text {corr }}=$ corrosion current density; $\mathrm{I}_{\text {pass }}=$ passive current density
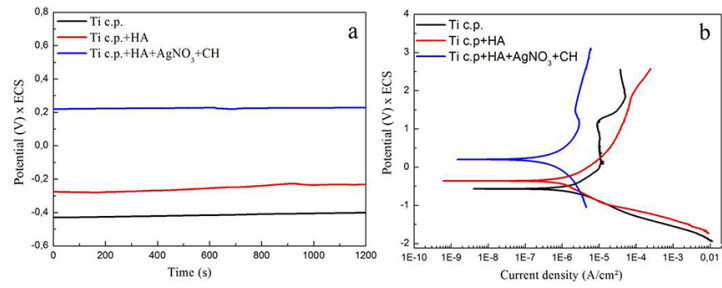

Figure 7. Assay of cp-Ti corrosion in $1.5 \mathrm{SBF}$ at $36.5^{\circ} \mathrm{C}$. (a) assay of open circuit potential (OCP). (b) assay of linear polarization.

The polarization curves in all conditions studied sowed a passive region. Current density in this region is constant in a wide range of potentials, indicating the formation of a compact passive film of titanium oxide on cp-Ti surface. It was possible to observe that in cp-Ti sample without coating, there is a noticeable passive region, where current density remained constant while the values of the potential suffered variation. This behavior indicates that a titanium oxide layer is formed, protecting the material. With the rise in potential, there is a break of the passive layer formed on $\mathrm{cp}-\mathrm{Ti}$, and when the potential around $1.6 \mathrm{~V}$ is reached, an oxide layer is formed again, indicating that the titanium oxide formed was adherent and stable on cp-Ti surface. Table 3 shows, by the Ipass values, that the formation of this film occurs is lower current densities for condition $\mathrm{C} 1\left(2.398 \times 10^{-6} \mathrm{~A} /\right.$ $\left.\mathrm{cm}^{2}\right)$, in relation to conditions $\mathrm{C} 0\left(5.472 \times 10^{-5} \mathrm{~A} / \mathrm{cm}^{2}\right)$ and cp-Ti without coating $\left(1.116 \times 10^{-5} \mathrm{~A} / \mathrm{cm}^{2}\right)$, indicating that for condition $\mathrm{C} 1$, the film is formed more rapidly.

It is observed, by the polarization curve of condition $\mathrm{C} 1$, that when reaching a current density value around $2.9 \times 10^{-6}$ $\mathrm{A} / \mathrm{cm}^{2}$ and potential of $1.2 \mathrm{~V}$, there is a partial rupture of the chitosan film, with a possible slow release of the silver ions, to act as bactericidal.

The corrosion potential at condition $\mathrm{C} 1$ was higher when compared to conditions $\mathrm{C} 0$ and the $\mathrm{cp}-\mathrm{Ti}$ without coating, which demonstrates that the coating with chitosan was more efficient than with hydroxyapatite, a behavior which was due to its higher stability and homogeneity in coating, also observed by Tiyyuagura et al. ${ }^{23}$.

\section{Conclusions}

Regarding cp-Ti characterization, a granular equiaxial structure can be observed, characteristic of Ti phase $\alpha$, homogeneously distributed in the matrix. The biomimetic coating was efficient and very homogeneous on the whole substrate, in hydroxyapatite formation. At condition $\mathrm{C} 0$ (cp-Ti+ HA), the layer formed presented hydroxyapatite constituents, such as calcium and phosphorus, and it was also possible to verify the presence of smaller hydroxyapatite globules and a continuous growth of layers. Chitosan coating was also efficient, being a homogeneous and porous coating. In the corrosion assay, it was possible to conclude that the open circuit potential in cp-Ti presented a variation of the potential with time, a fact that indicates the formation of a titanium oxide layer. For conditions $\mathrm{C} 0$ and $\mathrm{C} 1$, the potential remained virtually constant, being possible to conclude that the coatings were stable and adherent to the surface. At condition $\mathrm{C}$, the partial rupture of the chitosan film was observed, with the possibility of a slow release of the silver ions, with a bactericidal activity. Chitosan coating, condition $\mathrm{C} 1$, was more efficient than hydroxyapatite, condition $\mathrm{C} 0$, because of the higher values of corrosion potential and passive current density, promoting a higher stability and homogeneity in the coating with chitosan.

\section{Acknowledgements}

The authors gratefully acknowledge the Brazilian research funding agencies FAPEMIG (Minas Gerais State Research Foundation), CNPq (National Council for Scientific and Technological Development) and CAPES (Federal Agency for the Support and Improvement of Higher Education) for their financial and material support.

\section{References}

1. Agrawal CM, Appleford MR, Mani G, Ong JL. Introduction to Biomaterials: Basic Theory and Engineering Applications. Cambridge: Cambridge University Press; 2014.

2. Liu YT, Long T, Tang S, Sun JL, Zhu ZA, Guo YP. Biomimetic fabrication and biocompatibility of hydroxyapatite/chitosan nanohybrid coatings on porous carbon fiber felts. Materials Letters. 2014;128:31-34.

3. Tang S, Tian B, Guo YJ, Zhu ZA, Guo YP. Chitosan/carbonated hydroxyapatite composite coatings: Fabrication, structure and biocompatibility. Surface \& Coatings Technology. 2014;251:210-216.

4. Šupová M. Substituted hydroxyapatites for biomedical applications: A review. Ceramics International. 2015;41(8):9203-9231. 
5. Fraga AF, Almeida Filho E, Rigo ECS, Boschi AO. Synthesis of chitosan/hydroxyapatite membranes coated with hydroxycarbonateapatite for guided tissue regeneration purposes. Applied Surface Science. 2011;257(9):3888-3892.

6. Song L, Gan L, Xiao YF, Wu Y, Wu F, Gu ZW. Antibacterial hydroxiapatite/chitosan complex coatings with superior osteoblastic cell response. Materials Letters. 2010;65(6):974-977.

7. Abe Y, Kokubo T, Yamamuro T. Apatite coating on ceramics, metals and polymers utilizing a biological process. Journal of Materials Science: Materials in Medicine. 1990;1(4):233-238.

8. Coelho MFC, Cronemberger MER, Pereira JN, Nakamatsu S, Maestrelli SC, Rigo ECS, et al. A Comparative Study of Biomimetic Coatings on Titanium and Stainless Steel. Materials Science Forum. 2014;802:440-445.

9. Podporska-Carroll J, Quilty B, Devery R. Non-cytotoxic and antimicrobial plasma sprayed coatings for orthopaedic application. Materials Letters. 2013;112:54-57.

10. Mishra SK, Kannan S. Development, mechanical evaluation and surface characteristics of chitosan/polyvinyl alcohol based polymer composite coatings on titanium metal. Journal of the Mechanical Behavior of Biomedical Materials. 2014;40:314-324.

11. Hazra M, Mandal DD, Mandal T, Bhunya S, Ghosh M. Designing polymeric microparticulate drug delivery system for hidrophobic drug quercetin. Saudi Pharmaceutical Journal. 2015;23(4):429-436.

12. Mariano NA, Oliveira RG, Fernandes MA, Rigo ECS. Corrosion behavior of pure titanium in artificial saliva solution. Matéria (Rio de Janeiro). 2009;14(2):878-880.

13. ASTM International. ASTM F67-06 - Standard Specification for Unalloyed Titanium, for Surgical Implant Applications (UNS R50250, UNS R50400, UNS R50550, UNS R50700). West Conshohocken: ASTM International; 2006. DOI: 10.1520/ F0067-06

14. ASTM International. ASTM E3-95 - Standard Practice for Preparation of Metallographic Specimens. West Conshohocken: ASTM International; 2001. DOI: 10.1520/E0003-95
15. Manera RS, Rodrigues AR, Matsumoto H, Gallego J. Avaliação da integridade superficial de implantes dentários de titânio. In: V Congresso Brasileiro de Engenharia de Fabricação; 2009 Apr 14-17; Belo Horizonte, MG, Brazil.

16. Kokubo T, Yamaguchi S. Novel bioactive materials developed by simulated body fluid evaluation: Surface-modified Ti metal and its alloys. Acta Biomaterialia. 2016;44:16-30.

17. Majumdar P, Singh SB, Chakraborty M. The role of heat treatment on microstructure and mechanical properties of Ti-13Zr-13Nb alloy for biomedical load bearing applications. Journal of the Mechanical Behavior of Biomedical Materials. 2011;4(7):1132-1144.

18. Adawy A, El-Fattah IA, El-Sayed MES, Talaat M. Biomimetic Coating of Precalcified Ti-6Al-4V Alloy. The Open Medical Devices Journal. 2009;1:19-28.

19. Vercik LCdeO, de Assis CM, Lia Fook MV, dos Santos ML, Guastaldi AC. Recobrimento de apatitas "in vitro" sobre titânio: influência do tratamento térmico. Eclética Química. 2003;28(1):25-31.

20. Eraković S, Janković A, Veljović D, Palcevskis E, Mitrić M, Stevanović T, et al. Corrosion Stability and Bioactivity in Simulated Body Fluid of Silver/Hydroxyapatite and Silver/ Hydroxyapatite/Lignin Coatings on Titanium Obtained by Electrophoretic Deposition. The Journal of Physical Chemistry B. 2013;117(6):1633-1643.

21. Lafron JP, Champion E, Bernache-Assollant D. Processing of AB-type carbonated hydroxyapatite $\mathrm{Ca}_{10-\mathrm{x}}\left(\mathrm{PO}_{4}\right)_{6-\mathrm{x}}\left(\mathrm{CO}_{3}\right)$ ${ }_{x}(\mathrm{OH})_{2-x-2 y}\left(\mathrm{CO}_{3}\right)_{y}$ ceramics with controlled composition. Journal of the European Ceramic Society. 2008;28(1):139-147.

22. Zhou J, Cai X, Cheng K, Weng W, Song C, Du P, et al. Release behaviors of drug loaded chitosan/calcium phosphate coatings on titanium. Thin Solids Films. 2011;519(15):4658-4662.

23. Tiyyuagura HR, Rudolf R, Gorgieva S, Fucs-Godec R, Rao BV, Mantravadi KM, et al. The chitosan coating and processing effect on the physiological corrosion behaviour of porous magnesium monoliths. Progress in Organic Coatings. 2016;99:147-156. 